\title{
URGENSI PENGEMBANGAN KETERAMPILAN BELAJAR ABAD 21 DI PENDIDIKAN DASAR
}

\author{
Hermansyah dan Muslim \\ PGMI Fakultas Tarbiyah UIN Sunan Kalijaga Yogyakarta \\ Institut Agama Islam (IAI) Muhammadiyah Bima \\ Email: hermandompu95@gmail.com \\ muslimanjas@gmail.com
}

\begin{abstract}
Abstrak
Tulisan ini membahas tentang bagaimana mempersiapkan generasi emas yang siap bersaing di tengah arus globalisasi dan kompetensi-kompetensi yang perlu dimiliki oleh siswa. Bagi seorang guru bahwa mendidik generasi yang tangguh itu butuh kematangan intelektual, konsep, metode, strategi dan tujuan yang jelas. Sehingga materi yang disampaikan dapat diserap oleh siswa dengan mudah. Jenis penelitian yang digunakan dalam penulisan ini adalah penelitan kepustakaan (Library Research), yaitu serangkaian penelitian yang berkenaan dengan metode pengumpulan data pustaka, atau penelitian yang digali melalui beragam informasi kepustakaan seperti buku, ensiklopedi, jurnal ilmiah, koran, majalah, dan penelitian terdahulu yang dianggap memiliki relevan dengan tema penelitian. Hasil analisis dalam penelitian menunjukan bahwa arah pembelajaran harus digiring pada proses penguatan keterampilan dan kompetensi yang dibutuhkan. Kompetensi itu antara lain, Critical Thinking, Communication, Collaboration dan Kreatif-inovatif. Selain kompetensi ini guru juga harus menguatkan dengan nila-nilai dasar dalam islam yaitu kepribadian seperti, kejujuran, amanah dan adil.
\end{abstract}

Kata kunci: Pengembangan, Keterampilan Belajar, Abad 21

\section{PENDAHULUAN}

Lembaga pendidikan sebagai sentral pembelajaran memiliki peran dalam menyiapkan sumber daya manusia (SDM) terutama untuk peserta didik di pendidikan dasar agar mereka mampu bersaing di era globalisasi. Satu-satunya wadah yang dapat dipandang dan memiliki peranan inti dalam mengembangkan SDM adalah pendidikan, baik itu pendidikan formal maupun non formal. Perkembangan jaman menuntut para guru dan peserta didik untuk senantiasa dapat beradaptasi dengan, kecanggihan teknologi. Sebab dengan adanya keahlian di bidang ilmu pengetahuan teknologi elektronik dan komunakasi (IPTEK) yang memadai maka besar kemungkinan generasi akan dapat bertahan dalam menghadapi arus kehidupan yang serba canggih. 
Guru sebagai lokomotif peggerak dunia pendidikan harus mampu menguasai literasi teknologi, informasi dan komunikasi agar peserta didik tidak gagap teknologi (gaptek). Guru dalam hal ini harus mampu menunjukan kapasitasnya sebagai seorang pendidik, artinya tidak sekedar meberikan catatan di atas kertas melainkan harus faham tentang perkembangan teknologi sebab literasi ini sangat penting untuk diajarkan kepada peserta agar mereka memiliki kecakapan teknologi, sikap kritis, dan menelaah informasi dengan baik. Di era ini banyak sekali informasi yang beredar, dan bahkan tidak sedikit informasi-informasi hoaks yang beredar di medsos. (Winda Marlina, Dhitsaha Jayanti, 2019).

Selain menguasai Iptek, guru juga harus mampu membekali peserta didik dengan keterampilan yang dibutuhkan sesuai dengan tuntutan jaman yang akan datang. Era revolusi industri merupakan era perubahan dari teknologi mekanik ke teknologi digital, mulai dari perkembangan komputer hingga lahirnya internet, dari ponsel (telepon seluler) hingga munculnya situs-situs media sosial. Kemajuan teknologi memungkinkan terjadinya otomatisasi hampir di segala bidang tak terkecuali di bidang pendidikan. Perubahan tersebut tidak dapat dihindari oleh kalangan masyarakat, perkembangan iptek bagaikan gelombang sunami dan tidak dapat dibendung oleh kalangan manapu, tidak memandang masyarakat kalangan bawah, teratas, tertinggal, terdalam, namu perkembangan ini terus menjalar sampai pada tingkat lokal pedesaan.

Eggen dan Kauchak mengemukakan bahwa melek (literasi) teknologi telah menjadi keahlian dasar yang sangat penting setelah membaca, menulis dan berhitung (Eggen dan Kauchak, 2012). Pendidikan harus mampu menguatkan kompetensi dan keterampilan yang memadai agar peserta didik dapat berpartisipasi dalam masyarakat dan kesejahteraan hidupnya (Etistika Yuni, Dwi Agus, 2016). Dengan kemampuan itu generasi tidak tertinggal jauh dari perkembangan globalisasi dan salah satu cara yang efektif untuk menangkalnya yaitu lewat transformasi dan keaktifan seorang guru dalam mengembangkan teknik dan model belajar yang lebih menekankan pada peningkatkan kompetensi peserta didik dan memberikan pemahaman tentang 
pentingnya keterampilan hidup (life skill) termasuk kompetensikompetesi lain yang dibutuhkan di abad 21.

\section{TINJAUAN TEORITIS}

\section{Urgensi Keterampilan}

Dalam Kamus Besar Bahasa Indonesia (KBBI) versi online, keterampilan berasal dari kata "terampil" yang berarti cakap dalam menyelesaikan tugas, mampu dan cekatan, sedangkan keterampilan adalah kecakapan untuk menyelesaikan tugas. Soemardjan berpendapat bahwa keterampilan merupakan kepandaian melakukan suatu pekerjaan dengan cepat dan tepat, dalam hal ini ruang lingkup keterampilan sangat luas yang melingkupi berbagai kegiatan antara lain, perbuatan, berpikir, berbicara, melihat, dan mendengar ( ${ }^{1}$ Soemardjan, 2006).

Sejalan dengan hal tersebut Tri Budiharto, mengungkapkan bahwa keterampilan berasal dari kata dasar "terampil" yang mendapat imbuhan "ke" dan akhiran "an" yang merujuk kepada kata sifat. Terampil sendiri memiliki arti kemampuan bertindak dengan cepat dan tepat. Istilah lain dari terampil adalah cekatan dalam mengerjakan sesuatu. keterampilan juga dapat disebut kecakapan, dan kemampuan untuk mengerjakan sesuatu dengan baik (Tri Budiharto, 2008).

Adapun tujuan utama dari pembelajaran abad ke-21 adalah membangun kemampuan belajar individu dan mendukung perkembangan siswa menjadi pembelajar sepanjang hayat, aktif, dan pembelajar yang mandiri, oleh karena itu guru merupakan pelatih pembelajaran dan fasilitator yang memiliki ketermpilan yang baik dan menguasai teknologi, sehingga guru bisa mentransfer kepada peserta didiknya. Menjadi guru di tengah perubahan tidak cukup hanya dengan peningkatan profesionalisme yang ditandai dengan sertifikasi dan tunjangan profesi, kehadiran dan jumlah jam mengajar di kelas, namun harus dilakukan reframing rancangan pendidikan dan pembelajaran yang komprehensif, baik dari aspek lingkungan belajar, yakni ruang kelas yang mendukung proses pembelajaran, serta desain pembelajaran yang mudah dipahami serta menyenakan $\left({ }^{1}\right.$ Dede Rasyada, 2017).

Keterampilan disini adalah kemampuan siswa dalam memainkan peran atau membuat dan menciptakan karya yang bisa diterima orang 
lain. Keterampilan dalam membuat atau mewujudkan sesuatu, baik bersifat materi maupun nonmateri, sehingga bisa menjadi modal dalam mencapai tujuan di era revolusi industri 4.0. kemampuan dapat mewujudkan sesuatu apapun bentuknya dan bisa menjadi modal bagi seseorang untuk mencapai sebuah impian (Muhamad Nurul Ibad, 2007).

Keterampilan dapat pula menyangkut intelektual (intellectual skill). Salah satu tujuan yang diharapkan dalam pembelajaran adalah keterampilan intelektual. Intelektual merupakan jenis kemampuan siswa untuk berinteraksi dengan lingkungannya melalui syimbol atau konsep yang dimiliki setelah peroses pembelajaran sebagai penerapan atau refleksi hasil belajar (Suprihatiningsih, 2016). Keterampilan pada hakikatnya adalah suatu pengelolaan kegiatan belajar mengajar yang berfokus pada pelibatan siswa secara aktif dan kreatif dalam proses pemerolehan hasil belajar. Pendekatan keterampilan ini dipandang sebagai pendekatan yang paling sesuai dengan pelaksanaan pembelajaran di sekolah dalam rangka menghadapi perkembangan teknologi yang semakin cepat dewasa ini, dalam hal ini guru dapat menerapkan pendekatan belajar Inqiry-discovery yaitu suatu kegiatan penyelidikan untuk menemukan suatu konsep pemahaman (Hikmawati, 2016).

Sund \& Trowbridge, menyatakan bahwa discovery when an individual is involue mainly in using his mental prosses to mediate (discover) some consept or prinsiple. Proses penemuan yang terjadi ketika siswa terlibat dalam proses kegiatan menemukan suatu konsep ataupun prinsip (Sound dan Trowbridge, 1973). Kata discovery dikaitkan dengan kata inquiry sehingga akan tersirat makna yang sama, yaitu suatu kegiatan penyelidikan untuk menemukan suatu konsep pemahaman yang dilakukan (keterlibatan) sendiri oleh siswa. Siswa didorong untuk memiliki pengalaman dan melakukan percobaan yang memungkinkan mereka untuk menemukan prinsip-prinsip atau jawaban lewat percobaan (trial and error).

Dari beberapa definisi keterampilan di atas, dapat disimpulkan bahwa keterampilan adalah kelebihan atau kecakapan yang dimiliki oleh 
seseorang agar mampu menggunakan akal, ide, fikiran, dan kreatifitasnya dalam mengerjakan, mengubah, menyelesaikan, ataupun membuat sesuatu menjadi lebih bermakna sehingga menghasilkan sebuah nilai dari hasil pekerjaan tersebut. Keterampilan pada dasarnya akan lebih baik bila terus diasah dan dilatih untuk meningkatkan kemampuan, sehingga siswa mahir dan ahli terhadap bidang tertentu. karena menjadi seorang yang terampil harus memiliki keahlian khusus pada bidang tertentu atau lebih, seseorang haruslah dilatih melalui belajar dengan tekun supaya dapat menguasai bidang tersebut dan dapat memahami serta mengaplikasikannya dalam kehidupan atau tempat mereka bekerja.

\section{Pembelajaran Abad 21}

Berbagai organisasi mencoba merumuskan berbagai macam kompetensi dan keterampilan yang diperlukan dalam menghadapi abad ke-21. Namun, satu hal penting yang perlu diperhatikan adalah bahwa mendidik generasi muda di abad ke-21 tidak bisa hanya dilakukan melalui satu pendekatan saja. Beberapa organisasi tersebut dan hasil pengembangannya disampaikan sekilas sebagai berikut.

Wagner dan Change Leadership Group dari Universitas Harvard mengidentifikasi kompetensi dan keterampilan bertahan hidup yang diperlukan oleh siswa dalam menghadapi kehidupan, dunia kerja, dan kewarganegaraan di abad ke-21 ditekankan pada tujuh (7) keterampilan berikut: (1) kemampuan berpikir kritis dan pemecahan masalah, (2) kolaborasi dan kepemimpinan, (3) ketangkasan dan kemampuan beradaptasi, (4) inisiatif dan berjiwa entrepeneur, (5) mampu berkomunikasi efektif baik secara oral maupun tertulis, (6) mampu mengakses dan menganalisis informasi, dan (7) memiliki rasa ingin tahu dan imajinasi (Wagner, 2010).

Delors Report dari International Commission on Education for the Twenty-first Century, mengajukan empat visi pembelajaran yaitu pengetahuan, pemahaman, kompetensi untuk hidup, dan kompetensi untuk bertindak (Delors Report, 1996). Selain visi tersebut juga dirumuskan empat prinsip yang dikenal sebagai empat pilar pendidikan yaitu learning to know, lerning to do, learning to be dan learning to live 
together. Kerangka pemikiran ini dirasa masih relevan dengan kepentingan pendidikan saat ini dan dapat dikembangkan sesuai dengan keperluan di abad ke-21 (Scott, C.L, 2015). Pada bagian berikut dijelaskan sekilas tentang kompetensi dan keterampilan sesuai empat pilar pendidikan yang terdapat pada Delors Report.

\section{Learning to Know}

Belajar mengetahui merupakan kegiatan untuk memperoleh, memperdalam dan memanfaatkan materi pengetahuan. Penguasaan materi merupakan salah satu hal penting bagi siswa di abad ke-21. Siswa juga harus memiliki kemauan untuk belajar sepanjang hayat.

2. Learning to Do

Agar mampu menyesuaikan diri dan beradaptasi dalam masyarakat yang berkembang sangat cepat, maka individu perlu belajar berkarya. Siswa maupun orang dewasa samasamamemerlukan pengetahuan akademik dan terapan, dapat menghubungkan pengetahuan dan keterampilan, kreatif dan adaptif, serta mampu mentrasformasikan semua aspek tersebut ke dalam keterampilan yang berharga.

3. Learning to Be

Keterampilan akademik dan kognitif memang keterampilan yang penting bagi seorang siswa,namun bukan merupakan satusatunya keterampilan yang diperlukan siswa untuk menjadi sukses. Siswa yang memiliki kompetensi kognitif yang fundamental merupakan pribadi yang berkualitas dan beridentitas.

\section{Learning to Live Together}

Berbagai bukti menunjukkan bahwa siswa yang bekerja secara kooperatif dapat mencapai level kemampuan yang lebih tinggi jika ditinjau dari hasil pemikiran dan kemampuan untuk menyimpan informasi dalam jangka waktu yang panjang dari pada siswa yang bekerja secara individu (TIM PGRI, 2014).

\section{METODOLOGI PENELITIAN}

Jenis penelitian yang digunakan dalam penulisan ini adalah penelitan kepustakaan (Library Research), yaitu serangkaian penelitian yang berkenaan dengan metode pengumpulan data pustaka, atau 
penelitian yang digali melalui beragam informasi kepustakaan seperti buku, ensiklopedi, jurnal ilmiah, koran, majalah, penelitian terdahulu dan dokumen (Nana Syaodih, 2009). Penelusuran pustaka ini dibatasi pada pembahasan tertentu dalam rangka untuk memperoleh data penelitian. fokus riset pustaka ini yaitu pada pengkajian dan analisis terhadap berbagai literatur yang memiliki hubungan dengan tema penelitian dan diakhiri dengan penarikan kesimpulan sebagai hasil temuan dalam penelitian.

\section{HASIL TEMUAN}

\section{Pengembangan Keterampilan Belajar Abad 21}

Pengembangan keterampilan yang dimaksud dalam tulisan ini yaitu penguatan tentang proses, dan kurikulum yang digunakan oleh seorang guru atau pendidik dalam menumbuhkan keterampilan (skill) siswa agar peserta didik dapat memiliki kapasitas keilmuan yang baik. kegiatan pembelajaran tidak selalu berarti penambahan jam belajar dan pemberian materi, tetapi lebih dari itu yakni pengembangkan soft skill untuk membekali peserta didik di masa mendatang, karena dengan modal soft skill yang dipraktekkan setiap hari melalui tugas-tugas proyek sederhana yang diberikan oleh guru, peserta didik diharapkan makin siap dan tangguh dalam menghadapi masalah yang ditemukan di masyarakat maupun diinternal keluarganya sendiri.

Pengembangan keterampilan siswa merupakan salah satu tujuan sekolah yang sangan urgen, karena melihat prospek kedepan yang semakin maju di segala bidang, baik aspek pendidikan, ekonomi, komunikasi, dan politik, bahwa siswa dituntut untuk benar-benar memiliki berbagai kemampuan terutama keterampilan dibidang teknologi informasi dan komunikasi, sebab iptek merupakan otak informasi di era digital, melihat perkembangan dunia sekarang sangat mempengaruhi keidupan manusia, dulu guru mengajarkan siswa dengan menggunkan papan dan kapur sebagai media belajar, sekarang sudah berubah yaitu guru sudah bisa menggunakan leptop, hp, Lcd bahkan aplikasi sebagai media pembelajaran.

Kemampuan literasi teknologi dapat tercapai tentu membutuhkan peran pendidikan sebagai lembaga formal maupun non formal agar 
dapat meningkatkan taraf kesejahteraan hidup manusia. Menghadapi perubahan era reformasi serta proses globalisasi diperlukan suatu visi dan pembelajaran yang terarah, terutama dalam proses pembelajaran yakni harus berpusat pada siswa (student center) agar mereka dapat mengkonstruksi ide dan pengalaman sebelumnya sehingga dapat terkoneksi dengan apa yang sedang mereka pelajari dan menghubungakan dengan pengalamannya. Sebagai upaya untuk merespon miskinnya keterampilan dan ketertinggalan kita tentang perkembangan iptek yang pesat maka diperlukan langkah strategis terutama dalam dunia pendidikan yaitu perlunya pengembangan pembelajaran berbasis kompetensi dan keterampilan agar generasi di abad 21 mampu membendung arus globalisasi dengan basis keterampilan yang mereka peroleh dari hasil belajar.

Pengembangan kurikulum belajar menjadi hal yang sangat urgen guna menyesuaikan dengan target yang akan dicapai oleh peserta didik. Proses pembelajaran harus terarah dan memiliki visi yang jelas. Contoh: seorang anak diajarkan tentang tema akhlak mulia, tujuan belajarnya tidak sekedar mereka tau dan hafal tentang penegertian akhlak dan macam-macam akhlak, melainkan lebih dari itu yakni harus menjadi habit dan direalisasikan dalam kehidupan nyata, begitupun dengan pembelajaran yang lain termasuk tentang kecakapan hidup.

Dennis dan Van Roekel, presiden asosiasi menjelaskan bahwa berdasarkan hasil beberapa penelitian yang dilakukan di USA dalam sepuluh tahun terakhir, menunjukan bahwa kehidupan manusia di dunia sekarang ini sangat kompleks dibanding dengan 50 tahun yang lalu, karena mobilitas antara negara yang dilakukan masyarakat saat ini, interaksi sosial yang semakin mengglobal, komuniaksi sosial lintas negara, bangsa, budaya dan agama dengan menggunakan media virtual yang sangat cepat, formasi pekerjaan yang terbuka sangat lebar dalam berbagai variasi informasi yang sangat dinamis (Dennis Van Roekel, 2012). Berbagai tantangan dalam dunia kerja yang sudah tidak memerlukan para pekerja untuk menyelesaikannya sebab semuanya sudah model online yang sudah diprogram secara khusus bahkan sudah ada robot buatan sebagai pengganti manusia. Oleh karena itulah para 
siswa harus dipersiapkan keterampilan guna menciptakan dunia kerjanya sendiri sebagai sumber penghasilan, agar itu tercapai maka siswa harus dibekali dengan kompetensi yang disebut 4C, adapun kemampuan itu dapat divisualisasikan dalam gambar sebagai berikut;

\section{Gambar: Kompetensi siswa Abad 21}

\section{Critical Thinking}



Untuk menjelaskan kemampuan critcal thinking (berpikir kritis) penulis meminjam pandangan Emily. R. Lai, bahwa emil menjelaskan tentang berpikir kritis ini dalam dua sudut pandang yaitu secara filosofi dan psikologi. Menurut cara pandang yang pertama, berpikir kritis diartikan sebagai "cara berpikir yang bertujuan, berbasis regulasi, teori, konsep dan hasil analisis terhadap data, serta menggukan berbagai kriterian yang jelas dan terukur". Sementara dalam pandangan psikologis, critcal thinking sering dimaknai dengan "penggunaan keterampilan atau strategi kognitif untuk meningkatkan probabilitas pencapaian outcome yang diharapkan" (Emily R. Lai, 2011).

Kompetensi ini sangat penting untuk diajarkan pada siswa terutama di pendidikan dasar sebab di usia SD, anak-anak sangat mudah memahami karena otak seusia sekolah dasar masih belum terisi oleh banyak informasi sehingga mereka mudah menyerap apa yang telah diajarkan oleh guru di sekolah. Targetnya adalah anak sudah mampu menyampaikan argumen, mampu berpikir sistematis dan mampu merumuskan kesimpulan serta mampu menyelesaikan masalah secara efektif. Guru dapat menerapkan proses belajar dengan strategi pembelajaran berbasis masalah (Problem Based Learning), agar siswa terlatih untuk memikirkan solusi dalam menyesaikan masalah. 


\section{Communication}

Komunikasi adalah kunci sukses dalam hal apapun, jika komunikasi seseorang itu baik, penggunaan diksinya baik, mudah dipahami, pesanya singkat, jelas dan sesuai dengan outcome yang diharapkan maka dapat meyakinkan penerima pesan atau lawan bicara. Kompetensi komunikasi yang baik akan mempengaruhi penerima informasi untuk mengikuti atau setidaknya tidak melakukan penolakan terhadap informasi tersebut. Kompetensi ini menjadi penting karena dalam bisnis apapun, dalam profesi apapun, komunikasi merupakan salah satu bagian yang sangat vital yang tidak dapat terpisahkan dalam dinamika sosial. Komunikasi merupakan proses penyampaian informasi kepada orang lain baik secara langsung face to face maupun via telepon seluler secara lisan atau sejenisnya. Karena komunikasi secara lisan adalah sangat penting, maka perlu ditumbuh kembangkan sejak dini kepada peserta didi kemudian Komunikasi tulisan juga diperlukan sebab ini merupakan kecakapan bagaimana cara menyampaikan pesan secara tertulis dengan pilihan kalimat, kata-kata, tata bahasa, dan aturan lainnya agar mudah dipahami orang lain atau pembaca (Sofyan S. Willis, 1981).

Kompetensi komunikasi ini tidak ada dalam mata melajaran. Guru hanya bisa selipkan pada setiap mata pelajaran untuk memberikan kebebasan kepada siswa untuk bertanya, berargumen dan berdiskusi, karena hanya lewat pemebalajaran seperti ini guru dapat melatih dan mengasah kemampuan komunikasi anak. Oleh sebab itu, pembinaan kompetesi komunikasi juga menjadi mandat dalam proses pembelajaran pada semua mata pelajaran, karena peluang untuk mengembangka komunkasi anak hanya lewat proses pembalajaran.

Orientasi pengembangan kompotensi komunikasi di sekolah dasar adalah agar siswa dapat memiliki kemampuan dalam membangun hubungan yang baik, dengan keluarga sekolah maupun keluarga di rumah bahkan dengan teman bergaulnya. Anak 
diharapkan dapat menggunakan bahasa-bahasa yang sopan, halus, dan mudah dimengerti oleh lawan bicaranya.

3. Collaboration

Dalam berbagai pekerjaan seperti perusahaan sering kali melakukan hubungan kerja sama, apakah dengan membentuk konsorium untuk melakukan proyek yang sangat besar, atau hanya dengan mengembangkan kerja sama dengan saling membantu antara satu dengan yang lain dalam menyelesaikan sebuah pekerjaan atau melakukan kerja sama dalam mengembangkan bisnis antara produsen, distributor dan pemasaran.

Kolaborasi tiada lain adalah kerja sama dengan melakukan pertukaran informasi, mengembangkan berbagai pilihan kegiatan dan pekerjaan bersama, melakukan sharing sumber daya, meningkatkan kapasitas dari masing-masing organisasi untuk mencapai tujuan bersama, dan dikembangkan melalui jejaring kerja, koordinasi dan kooperasi antar institusi, dan organisasi.

Guru dalam mengembangkan kompetensi kolaborasi anak dapat dilakukan dengan banyak cara, salah satunya yaitu lewat pembelajaran kooperatif. Arends, menyatakan bahwa the kooperatif learning model was developed to achieve at least three important instructional goals: academica achievement, acceptance of diversity, and sosial skill development, yang masksudnya adalah model pembelajaran kooperatif dikembangkan untuk mencapai sekurangkurang tiga tujuan pembelajaran penting, yaitu hasil belajar akademik, penerimaan terhadap perbedaan individu, dan pengembagan keterampilan sosial.

Pertama hasil belajar akademik memberikan keuntunga lebih pada siswa kelompok yang cepat menyelesaikan tugas kelompok secara bersama, kemudian kelompok yang cepat selesai akan menjadi mentor untuk membantu kelompok lain dalam menyesaikan tugasnya. Untuk siswa kelompok yang jadi mentor tadi mendapatkan peningkatan nilai akademis karena sudah menjadi mentor pagi kelompok lain. Kedua pembelajaran kooperatif menyajikan peluang bagi siswa dari berbagai latar belakang dan kondisi, untuk bekerja 
dan saling bergantung antara satu dengan yang lain atas dalam menyelesaikan tugas bersama. Ketiga pembelajaran kooperatif mengajarkan kepada siswa keterampilan bekerja sama dan kolaborasi.

Dari penjelasan di atas dapat kita tarik benang merahnya bahwa kompetensi kolaborasi bagi siswa sangat penting. Guru sebagai fasilitator harus mampu mendesai strategi pembelajaran kooperatif guna menumbuhkan kesadaran siswa untuk dapat melatih diri berhungan dengan orang lain sehingga prospek kedepan siswa sudah bisa membangun jejaring sendiri dengan kompetensi yang sudah diajarkan oleh guru di sekolah. Kecakapan dan kemampuan seperti inilah yang dibutuhkan kedepan, contoh kongkritnya dapat kita lihat di syarat-syarat penerima kariyawan, salah satu poinya adalah mampu bekerja sama dengan tim serta dapat membangun komunikasi yang baik.

\section{Creativity and Innovation}

Sebagian orang memandang bahwa kreativitas adalah bawaan sejak lahir, dengan demikian hanya sedikit saja orang yang kreatif di dunia ini karena menganggap bahwa kreatifitas itu potensi bawaan. Akan tetapi para ahli pendidikan tidak mempercayai hal itu, sehingga sampai sekarang masih dirancang bagaimana mempersiapkan anakanak bangsa yang kreatif melalui proses pendidikan. Kreatif sendiri bermakna kemampuan untuk melahirkan sebuah gagasan, atau konsep baru untuk menyelesaikan sebuah masalah, atau disisi lain yaitu kemampuan untuk melahirkan prototype baru dalam menciptakan sebuah produk baru yang akan dihasilkan (Dede Rosyadah, 2017).

Pengertian di atas menyiratkan empat kriteria yang dimiliki oleh seseorang baru bisa dikatakan orang kreatif. Pertama kemampuan berpikir divergen yang bisa memberikan solusi berbeda dari yang lain tentang sebuah masalah. Kedua memiliki ilmu yang mumpuni dan disertai pengalaman sebelumnya. Ketiga memiliki kemampuan untuk berkomunikasi sehingga kita bisa bertukar informasi dengan rekan kerja atau bisnis. Keempat memiliki 
kapasitas dalam berpikir krits dan memiliki kemampuan analisis yang baik.

Untuk melahirkan siswa yang kreatif diperlukan atmosfer madrasah yang mendukung seperti sarana prasarana, ruang lingkup yang ramah dan nyaman, bimbingan yang efektif, kemudian guru yang memiliki kompetensi, pekerja keras dan komitmen. Dengan demikian maka tidak diperdebatkan lagi bahwa kreativitas itu dibentuk dan bukan bawaan sejak lahir. Kreativitas selalu berdampigan dengan inovasi, karena keduanya hampir sama, bahwa kreativitas selalu menuntut adanya pemikiran baru, gagasan baru untuk menyesesaikan masalah. Dalam proses berpikir kreatif ada fase yang dilewati untuk melahirkan sebuah formulasi baru, dan ada proses implementasi formulasi tersebut agar bisa digunakan dalam penyelesaian problem.

Sementara inovasi adalah cara baru dalam mengoperasikan formula baru tersebut. Oleh karena demikian, inovasi selalu datang setelah lahir karya-karya kreatif, hanya saja kreativitas tidak diakui sebagai sebuah karya kreatif kalau belum ada bukti produk baru dan model baru yang benar-benar distingtif dan membawa perubahan, sehingga ada juga definisi kreativitas itu adalah "bringing imagination in to being" kesimpulan tersebut sejalan dengan teori yang dikembangakan oleh Dennis Van Roekel, yang menurutnya hubungan antara kreativitas dan inovasi terdiri dari tiga tahap yaitu, berpikir kreatif, bekerja kreatif dan melaksanakan pekerjaan dengan inovasi baru.

Selain beberapa kompetensi yang dijelaskan di atas, guru juga harus membekali peserta didik dengan karakter Islamik. Sebab empat kompetensi itu tanpa diimbangin dengan nilai-nilai keislaman maka anak akan cenderung bebas dan melampaui batas dalam bertinfak. Tidak sedikit kasus pelecehan, korupsi, pembunuhan, jambret dan lain-lain. Pelakunya sebagian besar adalah orang terpelajar dan sebagiannya orang yang tidak berpendidikan. Sebagai langkah preventif yang harus dilakukan oleh guru dan orang tua adalah mengokohkan sikap anak-anak dengan karakter yang baik. 
Nilai-nilai yang dimaksud itu merupakan cerminan kepribadian Rasul utusan allah yaitu, Nabi Muhammad SAW, adapun kepribadian itu, pertama, adalah kecerdasan, baik itu cerdas secara intelektual maupun spritual. Kedua yaitu sikap jujur. Anak yang ditanamkan nilai kejujuran dari sejak kecil maka sampai dia dewasa nanti akan senantiasa menjadi standar dalam melakukan sesuatu maupu dalam memutuskan perkara, karena hal itu sudah jelas bernilai positif, baik bagi orang lain maupun bagi pribadi siswa. Ketiga adalah amanah, peserta didik sebagai generasi pelanjut estafet kepemimpinan dan pelanjut dakwa risalah islam harus ditanamkan sikap amanah, hal itu bisa dimulai dari hal-hal yang kecil di sekolah, seperti kumpul tugas tepat waktu, melaksanakan piket kelas dan lainlain. Keempat adalah adil, perkara adil ini sangat urgen untuk dibiasakan bagi peserta didik. Guru dalam menumbuhkan sikap adil terhadap peserta didik harus dengan keteladanan terutama dalam meberika nilai tugas siswa dan masih banyak contoh-contoh kongrit lainnya.

\section{SIMPULAN}

Dari hasil pembahasan dan analisis di atas maka penulis menarik kesimpulan menjadi beberapa poin. Pengembangan keterampilan siswa merupakan salah satu tujuan sekolah yang sangan urgen, karena melihat prospek kedepan yang semakin maju di segala bidang, baik aspek pendidikan, ekonomi, komunikasi, dan politik, bahwa siswa dituntut untuk benar-benar memiliki berbagai kemampuan terutama keterampilan dibidang teknologi informasi dan komunikasi, sebab iptek merupakan otak informasi di era digital.

Basis pembelajaran ditekankan pada proses pembentukan dan pengembangan kompetensi peserta didik sebagaimana tuntutan kebutuhan abad 21. Sehingga outputnya dapat dialami langsung oleh peserta didik setelah tamat sekolahnya. Kompetensi critical thinking, collaboration, kommunication dan kreatif-inavation, menjadi target akhir bagi para guru setelah terpenuhinya kurikulum pembelajan, hal ini agar anak didik mampu bersaing di tengah arus globalisai. Selain itu guru juga harus menanamkan nilai-nilai dasar islam untuk mengimbangi 
kemampuan anak, seperti kecerdasan, kejujuran, amanah, dan adil. Sikap ini menjadi perekat bagi peserta didik setelah tamatnya nanti bahkan sampai mereka mendapat pekerjaan. Pemahaman agama yang baik akan menjadi pengendali segala perbuatan peserta didik kedepan.

DAFTAR PUSTAKA

Delors Report. 1996. Learning: The Treasure Within: Report to UNESCO of the International Commission on Education for the Twenty-First Century. Paris, UNESCO.

Eggen dan Kauchak. 2012. Strategi dan Model Pembelajaran, (Mengajarkan Konten dan Keterampilan Berpikir, Edisi 6,). Jakarta, Indeks.

Etistika Yuni, Dwi Agus. 2016. Transformasi Pendidikan Abad 21 sebagai Tuntutan Pengembangan Sumber Daya Manusia di Era Global, Prosiding Seminar Nasional Pendidikan Matematika.

Hikmawati. 2012. Jurnal Publikasi Pendidikan Yang Berjudul, Penggunaan Pendekatan Keterampilan Proses Dalam Meningkatkan Hasil Belajar Pesawat Sederhana Siswa di Kelas V Sdn 51 Lambari, Publikasi, Volume II No.1

Ibad, Nurul, Muhamad. 2007. Suluk Jalan Terabas Gus Miek, Cet; I. Yogyakarta: Pustaka Pesantren

Nana Syaodih. 2009. Metode Penelitian Pendidikan, Bandung: PT. Remaja Rosdakarya.

Rasyada, Dede. 2017. Madrasah dan Profesionalisme Guru, (Dalam Arus Dinamika Pendidikan Islam Di Era Otonomi Daerah), Jakarta, Penerbit, Kencana.

R. Lai, Emily. 2011. Critical Tinking: A literatur Review. Research Report, Pearson.

Scott, C.L. 2015. The Futures of Learning 2: What kind of learning for the 21st century? UNESCO Education Research and Foresight, Paris. (ERF Working Papers Series, No. 14).

Sofyan S. Willis. 1981. Problema Remaja dan Pemecahannya, Bandung: Angkasa.

Soemardjan. 2002. Pendidikan Keterampilan, Malang: Universitas Negeri Malang Press,

Sound dan Trowbridge. 1973. Teaching Science By Inquiry In The Secondary School. Ohio: Charles E. Merril Publishing Company.

Suprihatiningsih. 2016. Perspektif Manajemen Pembelajaran Program Keterampilan, Cet; I. Yogyakarta: Deepublish.

Tri Budiharto. 2008. Pendidikan Keterampilan, Surakarta: UNS Press,

Tim PGRI. 2014. Pendidikan Untuk Transformasi Bangsa: Arah Baru Pendidikan Untuk Mental Bangsa, Jakarta, PT Kompas Media Nusantara.

Van, Roekel, Dennis. 2012. Preparing 21st Century Student For a Global Society, an Educator,s Guide to the Four Cs. USJA: Nasional Education Association.

Wagner. 2010. Overcoming The Global Achievement Gap (online). Cambridge, Mass, Harvard University. 
Winda Marlina, Dhitsaha Jayanti. 2019. 4C dalam Pembelajaran Matematika Untuk Menghadapi Era Revolusi Industri 4.0, (Prosiding Sendika: Vol 5, No 1. 